\title{
THE HANDMAIDEN'S REVENGE: ON READING AND USING THE NEWER SOCIOLOGY OF CIVIL PROCEDURE
}

\author{
David M. TRUbeK* \\ I \\ INTRODUCTION
}

This symposium offers an opportunity to present some important developments in the empirical study of civil disputes, litigation, and procedure. In recent years, a few scholars working in the Law and Society tradition have outlined a new approach to the study of these phenomena and have articulated new themes that challenge conventional understandings of the social role of law. This article seeks to clarify this approach-which shall be called the "critical sociology of civil procedure"-and outline some themes emerging in recent Law and Society literature.

There are two fundamental ideas that make these newer studies distinctive. The first is an altered view of the relationship between law and subjectivity. Legal thought has long been concerned with this relationship, and the question of how law and the human subject intersect has existed for a long time. However, most discussions of this question have, implicitly or explicitly, taken the nature of the subject, and the relationship between law and subjectivity, as unproblematic. While conventional legal and sociological thought assumes that subjects approach the law with preconstituted aims that the law seeks to foster, critical sociology of civil procedure explores ways in which law simultaneously creates the subject and yet denies authentic subjectivity.

The second fundamental idea adopted in the newer literature is that social research is part of the process by which social reality is constructed. Earlier understandings have seen the nature of empirical research in legal studies as the mirroring of a preexistent reality, designed to bring to light objective and possibly invariant laws of human interaction. Rejecting this notion, the critical sociology of civil procedure posits that social research is one of the ways we construct society.

A truly critical approach to the study of civil disputes was born when these two themes-the legal construction of the subject and the construction of

\footnotetext{
Copyright (C) 1988 by Law and Contemporary Problems

* Voss-Bascom Professor of Law and Director, Institute for Legal Studies, University of Wisconsin-Madison. The author gratefully acknowledges the assistance of Lisa Bower, of the University of Wisconsin-Madison, Department of Political Science and the Institute for Legal Studies. in the research and analysis of this article.
} 
society through knowledge-were united. This union affects the way scholars define their roles and conceive the object of their study. Several scholars in the Law and Society tradition who study disputes and civil litigation have come to accept this approach. Thus, it is reasonable to speak of a critical sociology of civil procedure.

To understand a critical perspective in social thought, one must understand the classical jurisprudential tradition against which the critics react. The basic premise of this article is that the newer Law and Society literature is a critique of the social vision of self, society, and law that underlies much of our thinking about civil procedure today. This social vision is a set of ideas about the nature of personhood, the function of law, and the operation of procedure, which was articulated in the nineteenth century and which has survived, with some significant modifications introduced by Legal Realism, to the present. Part II of the article sets forth the original nineteenth-century social vision; Part III discusses the modifications introduced by Realism. Following these introductory discussions in which the social vision underlying mainstream thought is sketched out, the article turns to the critical work itself. Part IV introduces two major developments in recent social theory that have led some Law and Society scholars to raise basic questions concerning the mainstream social vision. Part V presents an outline of the newer work by identifying six themes that can be seen in the literature: (1) law's denial of an authentic self; (2) the legal construction of self and society; (3) victimization of victims through law; (4) the communitarian alternative and the critique of adjudication; (5) the critique of alternative dispute resolution ("ADR") and the discourses of need; and (6) the discursivity of social knowledge.

\section{II}

\section{Transparent Procedure: A Provisional Account of the IMPLiCATIONS OF THE Classical THEORY OF LAW FOR Civil Procedure}

To identify the social vision underlying mainstream thought about procedure, one must first understand the nineteenth-century social vision, many elements of which still animate current thinking. To gain such an understanding, one must look back at what shall be called, following the work of several legal historians, the age of "classical legal thought,"' a mode of thinking about law whose influence spans a 100 -year period from the midnineteenth to the mid-twentieth century." The social vision underlying

1. This term is taken from Kennedy, Touard an Luderstanding of Legal Consriousness: The Casp of Classical Legal Thought in America, 1850-1970, in 3 Resfarch in I aw and Sociology 3 (1980). For further development of the idea of classical legal thought, see Singer, The Legal Rights Debate in Analylical Jurisprudence from Bentham to Hohfeld, 1982 Wrs. L. REv. 975. See also Singer. Legal Realism Now (Book Review), 76 Calif. I.. Rev. 465 (1988).

2. Identification of periods is an imprecise process in intellectual history. Kennedy pinpointed the beginning of classical legal thought in 1850 and its end in 1940. Kennedy, supra note 1 , at 3. 
classical legal thought still influences current thinking about procedure, and it is important to understand the principles that animated classical thought and trace their implications in the realm of civil procedure.

Unfortunately, no such account is currently available. There have been a number of studies that have sought to identify the basic ideas about law and society that dominated in the classical period." No one, however, has worked out the procedural implications of these ideas. Thus, the account needed to begin this story must be created, not found. This section provides a provisional sketch, deriving notions of procedure from the more basic ideas of the nature, function, and operation of law that prevailed in the classical period. This sketch will represent the idea of "transparent procedure."

\section{A. Classical Legal Thought ${ }^{+}$}

Classical legal thought was based on three fundamental commitments: an individualist understanding of personhood, a liberal theory of society, and a formalist understanding of law. To understand why these commitments lead to a notion of the transparency of procedure, one must examine each of them and see how they interrelate.

1. Personhood.5 In classical thought, the person, and thus the legal subject, is a fully constituted, self-contained actor capable of autonomous choice. Not all human beings meet these standards of personhood, so that not all can be legal subjects. For example, children, married women, and the insane cannot be subjects in this sense. On the other hand, those who pass the test of personhood, such as white males, are presumed to be capable of acting in accordance with a set of values that they have freely chosen. In classical thought, these values and the choices to which they lead exist wholly independently of the law.

2. Liberalism." In a liberal society, the purpose of law is to protect the autonomy of the individual. Thus, the law must be designed to ensure that individuals are free to exercise the choices that they make, subject to a like freedom on the part of all others. To ensure that freedom, the law confers powers on individuals and provides immunities from the deprivations of

3. See supra note 1 and sources cited therein. See also Peller, The Melaphysics of American Law, 73 Calif. L. REv. 1151. $1193-219$ (1985).

4. The account of classical legal thought in this section is a synthesis drawn from many sources For the most important of these sources, see suph note 1 and sources cited therein; R. UNGER, Knowledge and Pol.Tics (1975); R. Unger, LaW in Modern Society (1976); 2 M. Weber, Economy AND Society 641-900 (G. Roth \& C. Wittich eds. 1980); Kennedy, Form and Substance in Priate Lata Adjudication, 89 HARv. L. REv. 1685 (1976). For an interpretation of Weber's vicws on classical legal thought, which Weber called formal legal rationality, see Trubek, . Wax ITeber's Tragic . Modernism and the Suludy of Law in Soriply, 20 LAw \& Soc'y Rrv. 573 (i986).

5. Sep R. Uncer, Knowlfoge and Pol.ticics, supra note 4, at 29-62; R. Unger. I aw in Modern Socityr, supre note 4 , at $23-37$

6. The classic account of this argument can be found in J. Locke. Two Tracts of Government (P. Abrams ed. 1967). For a critique of the autonomous subject of liberalism, see M. SANDEt.,

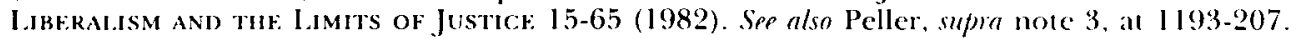


others. Thus, liberalism is not anarchy but rather a system of ordered liberty. It requires a system of law in which some actions chosen by individuals can be prohibited. The law, however, must distinguish between a sphere in which the individual can remain free of all external constraint and a sphere in which such constraint is not only permissible but necessary, because without such a distinction, one person's freedom will become another's domination.

3. Formalism. $^{7}$ In order for law to protect the individual and to serve ordered liberty, it must be formal in its operation. It must be able to delimit the spheres of freedom and regulation correctly; to define the scope of powers and immunities clearly; and to operate predictably. If the spheres are defined incorrectly, the law will not bring about the desired optimal liberty. If the boundaries of powers and immunities are not clear, and if the responses of legal institutions are not predictable, actors will not be able fully to exercise their autonomy for fear of incurring sanctions. A formal system of justice is simply a name for a legal system that can draw correct lines and adhere to them. Law is conceived as a set of statements from which specific rules covering all social interactions can be derived through techniques that all who have the proper training can use to reach the same result. For those who adhere to formalism, legal knowledge is both determinant and objective: There is one right answer and everyone must accept it.

\section{B. Transparent Procedure}

The classical theory of law presupposed that subjects were autonomous and preconstituted. Further, it assumed that the law established clear and determinate spheres in which they could-or could not-exercise free and unconstrained choice. The boundaries of these spheres were set by rights that derived from legal rules. " These rights had to be clear and knowable, because otherwise the individual would not know the boundaries of the sphere of autonomy that the whole system was designed to protect."

In such a system, procedure is a medium through which the correct rule is applied to the facts of a dispute. Given the premises of formalism, there must be a correct rule for any set of facts. And given the premises of liberalism, it will-from time to time-be necessary to apply these rules to those who intrude on protected spheres.

Anyone who accepts these principles must think of procedure not simply as a medium, but as a transparent medium-one that does not add or subtract anything. The rules of a formalist system are already there. The correct rule is not made; rather, it is discovered through procedure. Procedure should not make a difference in the outcome of a dispute. It should simply ensure that the system generates the right answer, an answer which, by hypothesis, is

7. For a description of formalism as a component of classical legal thought, see Singer, Legal Realism lou', supra note 1 , at 496-99.

8. Sep Kennedy, supra note 4; Singer, Legal Realism . Sow, supra note 1, at 475-95.

9. Sep Kennedy, supra note 4, at 1728-31. 
already present in the determinant system of formal law. Classical thought demands a procedural system that minimizes the chance of mistakes in selection of the right legal principle or determination of the correct facts, but it assumes that there are such principles and facts, so that transparency is a realizable goal.

Another feature of transparency is the idea that procedure should have no effect on the values, goals, and desires of those who use the system. By hypothesis, the legal subjects of classical thought come to the law with their goals already determined; the law should either support their claims or reject them. The law should not attempt to change their goals or their reasons for these goals, for to do that would violate the principle of autonomous personhood and the idea that the law serves only to carry out the goals chosen by individuals. Transparent procedure takes the litigants as they come to the court.

Classical legal scholars did not have a conscious concept of procedural transparency because it never occurred to them that procedure should be anything else but transparent. This does not mean that in the classical era no one worried about procedure; of course people did. But the author's hypothesis-and without further historical study it can be no more than thatis that in classical thought the goals of procedure were relatively unproblematic. Procedure was to be the handmaiden of justice, as justice was defined in classical thought. That definition implied that procedure should be a scientific instrument designed to identify the correct principle and determine the true facts. It should ensure that subjects can both invoke known rules in appropriate situations and be sure that these rules are enforced. If procedure erects barriers to the invocation of preexisting rights, or skews the outcomes dictated by the appropriate rules, it has failed in its role of handmaiden.

This attempt to deduce a theory of procedure from the premises of classical legal thought may make classical legal scholars sound naive. Could they really have thought that people who sought to use the the law would remain unaffected by their contact with it? Could they have imagined that procedure had no impact on the substantive outcome of cases? The author doubts that they were so naive. But that is not the point. The question is not how they assessed the actual legal institutions of their day, but whether they thought transparency was a feasible and desirable goal. The author, although unable to prove it, thinks that they did. Certainly, for a long period in history, the legal elite believed in the classical idea of law, ${ }^{10}$ and the notion of transparency is simply a deduction from the premises of that idea. To the extent that classical legal theorists thought about procedure at all, therefore, they must have imagined that what has been called transparency was a viable goal even if it was not a present reality.

10. Sef Kennedy, supma note 1, at 4-5: Singer, L.egal Realism . Nou', supra note 1, at 478+82. 


\section{III}

\section{Legal Realism and the Origins of EMPIRICAL Research on Civil Procedure}

Legal Realism ushered in a new era in legal thought. The Realists altered some aspects of the classical account of law, while retaining others. " They rejected the classical picture of legal knowledge as objective and determinant, while holding onto the classical notion of the autonomous subject. This shift in theories about law had a direct impact on procedural thought. The idea of procedural transparency, which rested on classical premises regarding the determinacy of legal knowledge, ceased to make sense. In its place came the forthright recognition that procedure and substance were inextricably intertwined.

One of the results of Realist thought about civil procedure was the development of empirical research on civil litigation and procedure. As is well known, the Realists, led by Charles E. Clark, initiated the tradition of empirical study of courts, litigants, and litigators and conducted the first systematic social scientific studies of procedure. ${ }^{12}$ The Realist era gave rise to the idea of empirical research as an auxiliary to civil procedure reform: a handmaiden's handmaiden, as it were. This tradition was taken up by the Law and Society movement in the 1960's.13 Today's critical sociology of procedure continues and at the same time seeks to reshape that tradition.

The Realists' interest in empirical research was not limited to civil procedure; empirical research was central to the Realist program for reasons that transcend its role in procedure. ${ }^{1+4}$ Moreover, the changes in thinking about civil procedure that the Realists initiated did not, by themselves, necessarily point to empirical research, any more than classical thought would have precluded empiricism. However, the Realists' views about law, which questioned the determinacy of rights and highlighted the inseparability of procedure and substance, ${ }^{15}$ made empirical research appear more important than it would have seemed to classical theorists. And these views helped shape the agenda of empirical study that emerged after Realism.

\section{A. The Indeterminacy of Rights}

Classical legal thought assumed that rights were knowable. Classical theorists thought of legal doctrine as unequivocal; they assumed that there was a determinate method that could be employed to identify the correct rule

11. Sep Singer, Legal Realism Nou', supra note 1, at 482-95.

12. For a thorough discussion of early Realist-inspired studies and Clark's rolc, see Schlegel, American Legal Realism and Empirical Social Scienre: From the Vale Experience, 28 Buffalo L. REv. 459, $491-569(1979)$.

13. The empirical research on litigation by Law and Society scholars is voluminous. For a survey and useful bibliography of work up to 1980-81, see Special Issue on Dispute Processing and Cizil Litigation, 13 LAW \& Soc'Y REv. 391 (1980-81).

14. For a fuller analysis, sec Trubek \& Esser, "Critical Empiricism" in American Legal Studies: Paradox, Program, or Pandora's Box?, 14 I.AW \& Soc. Inquiry 3, 8-10 (1989).

15. Sep infra notes $16-23$ and accompanying text. 
for any given set of facts. Furthermore, facts were thought of as objective, and questions of fact and law were presumed to be distinct. Thus, procedure would serve its function and be completely transparent as long as it led to a finding of the true facts and application of the correct rules.

Realist thought made procedure seem more important and yet more problematic than it had appeared in the classical understanding. The Realists argued that legal doctrine contains alternative and often conflicting answers to legal questions, so that often there is no one correct answer. "i They believed that verbal formulations of legal rules and concepts could never be precise and fixed enough so that they would necessarily generate clear answers to novel questions. ${ }^{17}$ Realists saw that there was no bright line between fact and law, and that the choice of the appropriate legal rule should only be made after a full analysis of the factual situation in dispute. ${ }^{18}$ Finally, they recognized that the process of adjudication frequently, if not always, involves contextual and situational analyses in which questions of policy must be considered in light of the particular facts of specific disputes. ${ }^{19}$

\section{B. Effect on Thinking About Procedure}

Revisions of the classical understanding had a subtle impact on thought regarding the nature and importance of procedure. To Realists, procedure seemed even more important than it did to classical theorists because it was inextricably linked to substance. Realism made it clearer that adjudication involved lawmaking, even if that was seen to be interstitial. Due to the Realists' view of the indeterminacy of rights and the contextual nature of legal judgment, this sort of micro-lawmaking seemed to be desirable and not anomalous or improper.

In this context, transparency could no longer be the sole goal of procedure. If every lawsuit was a micro-lawmaking process in which rules were defined and redefined in light of a rich understanding of social context, if concepts of fact and law were not objective categories but were to be defined relative to each other, and if in any situation there were multiple and possibly conflicting rules the court might draw on, then the clear line between substance and procedure which classical thought had drawn would have to be reconsidered. Once that was done, procedure began to seem both more

16. See, e.g., Llewellyn, Some Realism About Realism-Responding to Dean Pound, 44 HARv. L. REV. $1222(1931)$.

17. Sep, e.g. Cohen, Transcendental . Sonsense and the Functional tpproach, 35 Colum. L. REv. 809 (1935).

18. See generally Note. Plansible Pleadings: Dezeloping Standards for Rule II Sanctions. $100 \mathrm{HARV}$. L. REV. $630,645-47$ (1987).

19. The Harvard note describes this very well:

The Realists | believed that legal rules grew out of the factual circumstances of the cases to which they applied. . . According to the [R]ealists, judges create new rules of law every time they decide cases... |O/nce law is understood as logically indeterminate, judges' institutional authority plays a larger role in doctrinal decision making . . . UJudges did not merely perceive the law-they made it.

Id. at $646-47$. 
important and more complex than it had in classical thought. It was no longer just a question of setting up machinery to get the true facts and the correct rule, since these did not exist, at least in the classical sense.

This shift in thought had many ramifications. For present purposes, the most important was to highlight the utility of empirical research on the operation of the courts. Post-Realist thinking about civil procedure highlighted the importance that differences in procedural arrangements could have on substantive outcomes. Since it became accepted that various doctrinal answers were available and different "factual" accounts plausible, post-Realist legal science could not provide the one correct solution against which actual outcomes could be measured. In this context, attention shifted to questions of process and participation. Instead of measuring procedure by whether it produced the "correct" outcome, post-Realist thought tended to evaluate procedure in terms of the opportunities it provided for full participation of affected interests. Empirical research seemed to be a useful, if not indispensible, tool in this task. Thus, it is no surprise that studies of process and participation flowered in the Law and Society research that began in the post-Realist period. ${ }^{\circ}$

Indubitably, the classic in this genre was Marc Galanter's widely cited article entitled "Why the 'Haves' Come Out Ahead."' 21 While the somewhat polemical title might suggest that Galanter was conducting a class-based analysis of substantive bias in civil litigation, the study actually focuses on the fairness of adjudicative and quasi-adjudicative processes. Moreover, while Galanter identified structural features of litigation practices and procedures that tended to favor organizational over individual litigants, ${ }^{22}$ he thought these barriers to a fair process could be overcome by adjustments in civil procedure and through provision of certain kinds of subsidized advocacy.2:3

Thus, it is possible to argue that Legal Realism fostered a sociology of civil procedure. Moreover, one can describe this sociology as a critical practice, in a sense. After all, it was because procedure had become more salient and problematic that empirical inquiry into its operations and effects seemed so important to post-Realist scholars. However, the scope of this critical practice was rather limited, at least in light of recent developments. First, much of the work took the goals and aspirations of the procedural system at face value. Scholars recognized that things might not work out in practice as expected, but they accepted the view that the system was committed to its ostensible

20. The emphasis on process was apparent in the proliferation of studies of access to justice, a major theme in Law and Society rescarch. See, e.g., Access to Justick and The Wel.rare STATE (M. Cappelletti ed. 1981). See also Cappelletti \& Garth, Acress to Justice: The Newest llaze in the Itorlduide Movement to llake Rights Effective, 27 Buffalo L. Rev. 181 (1978).

21. Galanter, IIhy the "Haves" Come Out thead: Speculations on the Limits of Legal Change, 9 L aw \& Soc'y REv. 95 (1974).

22. Id. at $119-24$.

23. Id. at $135-44$. 
goals. ${ }^{24}$ For example, Galanter never really questioned that, once it was shown that his "haves" really came out ahead, someone would want to do something about it."25 Similarly, Wayne Brazil's study of discovery abuse, one of the most vehement empirical criticisms of the operation of civil procedure produced in recent years, seems to assume that, if we can demonstrate that discovery is being used for purposes inconsistent with its alleged goals, reform will follow. ${ }^{2} \mathrm{i}$

The second limiting feature of the post-Realist sociology of civil procedure was its tendency to accept the classical idea of the autonomous subject. Although Law and Society scholars had incorporated all of the Realist critiques of classical thought, this feature of the older tradition was not really questioned. A few studies did begin to explore how lawyers manipulated clients, 97 but by and large it was taken for granted that subjects came to the legal process with fully constituted aims untainted by contact with legal institutions or legal ideology.

\section{IV \\ Theoretical Shifts-Questioning the Subject}

Contemporary social and legal theory has raised questions about the liberal idea of the self and the role of law in self-empowerment and, thus, has put into question fundamental aspects of the post-Realist account of civil procedure that is grounded on such liberal notions. These theoretical developments have influenced the critical sociology of law, leading scholars to ask new questions and articulate new themes. Two major ideas have been central to this process: the discursive constitution of subjectivity and the contextual nature of the self.

The term "discursive constitution of subjectivity" refers to the idea that the self is not a natural entity independent of social relations, but rather is created through social practices, or discourses. Where classical liberalism posited a natural self, many strands in post-liberal thought emphasize the socially created nature of our subjectivity. Some who embrace this idea take it to the point of denying the existence of anything one could properly call self. This is the position usually associated with the French philosopher Michel

24. For an claboration on this view. sec Silbey \& Sarat, Critical Traditions in Law and Society Research, 21 Law \& Soc'Y Rev. 165 (1987); Silbey \& Sarat. The Pull of the Poliey tudience, 10 Law \& Pol.'y 97 (1988). Sep also l'rubek \& Fsser, supra note 14, at 14-19.

25. Sef Galanter, supra note 21, at 135-44. Post-Realist Law and Socicty work shows an implicit faith in the viability and normative correconess of liberal legalism. In other words, the underlying values of the system were never questioned; justice was viewed as a determinate concept with fixed meaning rather than as a symbolic construction that could be used by various groups both to advance ideological programs and to ignore entirely calls for social change.

26. See Brazil, The Aduersary Character of Cinil Discozery: th Chilique of Proposals for Change, 31 Vand. I. RFv. 1995 (1978).

27. See. P.g. Blumberg, The Practice of Late as Confidence Game: Orgamizalional Cooplation of a

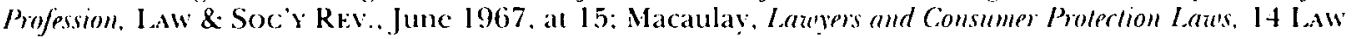
\& Sor'y Rry. 115 (1979). 
Foucault. ${ }^{28}$ Foucault sees the individual as nothing more than the result of "disciplinary power." "erg For Foucault there is no self, but only individuals who are simply the product of various disciplinary practices and discourses. ${ }^{30}$

Foucaultian themes appear in the critical sociology of procedure. But the notion of discursive constitution of subjectivity is not necessarily limited to Foucault's bleak picture of the disappearance of the subject. It also is associated with another idea which can be called the contextual self. Some social theorists who reject liberal premises about the subject have put forth an alternative account of the subject, one that stresses the importance of relations and social contexts rather than isolation and autonomy. Authors who posit the contextual self criticize the liberal notions of rights and thus of rights enforcement as inconsistent with genuine self-empowerment.31

The idea of a contextual self has many roots and appears today in many versions, but a particularly powerful and relevant example of this notion appears in the recent work of Roberto Mangabeira Unger. In a short volume called Passion ${ }^{32}$ and in an extensive treatise entitled Politics, ${ }^{33}$ Unger has developed a concept of the contextual self and a social theory that is aimed at creating the conditions for empowerment of such a subject. For Unger, the self is a source of infinite possibilities, but these possibilities can only be realized within contexts-that is, in personal and political relationships. ${ }^{34}$ To empower the contextual self, it is essential to create conditions of trust, solidarity, and "plasticity," or institutional revisability. 35 Because liberalism fails to grasp the contextual nature of authentic selfhood, Unger argues, it stresses the negative values of freedom from social constraint while underplaying the importance of constructing institutions that foster trust, solidarity, and plasticity. ${ }^{36}$

28. Sep gemerally M. Foucault, Discipline and Punish (1977); M. Foucault, The History of Sexuatity (R. Hurley trans. 1978); M. Foucault, Powfr/Knowltide: Ski.foted InTerviews and) Other Writings (C. Gordon ed. 1980). A key element of Foncault's work is the relationship between power and knowledge, which is integral to redefining the individual as an obedient subject. As the body becomes a target for new and refined mechanisms of power, it is offered up to new forms of knowledge. The individual can be known, described, compared to the norm, and therefore controlled. Legal discourse is only one discourse among many that are part of this process of normalization.

29. M. Foucalite, Power/Knowledge, supra nolc 28, al 156, 170.

30. This argument is developed most forcefully in M. Fouchurt, Power/Knowledge, supra note 28. See also H. Dreifus \& P. Rabinow, Michel Foucallit: Bryond Structuralism and HERMENEUTICS 143-68 (1983).

31. See generally Gabel, The Phenomenology of Rights-Consciousmess and the Pact of the llithdraum Selves. 62 IEx. I. REv. 1563 (1984). For a related perspective that criticizes the Kantian foundations of liberalism and the theoretical limits of a liberal definition of the self, see M. SANDEL, supra note 6 , at 14. 50-65. 175-83.

32. R. Unger, Passion: An Essay on Personality (1984).

33. R. Unger. Politics: A Work in Constructive Social Theory (1987) (three vols.).

34. Sep R. UnGik, supra note 32. at 5-22.

35. See R. Unger, Piasticity into Power 1-2 (1987); R. Unger. Sochal. Theory: Its Situation and Irs Task $1-17$ (1987). Sep also R. Unger, The Critical Legal. Studifs Movemfat 25-42 (1986).

36. For a summary of Unger's views. see Trubek, Programmatic Thonght and the Critique of the Social Disciplime, in Cerrieur. and Construction (M. Perry ed. forthcoming 1989 ). 
The themes of discursive constitution of subjectivity and the contextual nature of the self have affected legal scholarship in recent years. They can be seen, for example, in the much-debated (and frequently misunderstood) Critical Legal Studies "critique of rights." 37 Authors working in this tradition have argued that rights discourse presumes that individuals have full, autonomous access to an understanding of their natural interests, thus ignoring the way social practices and ideologies construct these very understandings. ${ }^{38}$ Furthermore, the critique of rights draws attention to the relational and contextual nature of selfhood, criticizing legal practices that individualize conflict and isolate disputes from the social contexts and relations in which they are embedded. ${ }^{3 ! 9}$

Those who accept the discursive nature of subjectivity and the relational nature of the self must question those aspects of the classical account of civil procedure that were left untouched by the Realist critiques. They are forced to recognize that the legal system, broadly conceived, may contribute to the constitution of the subject, rather than merely fostering (or frustrating) the ends of a preconstituted and autonomous self. At the same time, they must confront the fact that the legal system, as currently conceived, may deny the relational or contextual nature of the self, thus frustrating the realization of authentic selfhood. These broad ideas undergird the scholarly tradition herein called the critical sociology of civil procedure. They have generated a series of new themes. The next part of this article outlines these themes.

\section{Emerging Themes in the Critical Sociology of Procedure}

Affected by these developments in social theory, legal sociologists have articulated a series of critiques of litigation, procedure, and social research itself. These are: (1) the denial of the authentic self; (2) the legal construction of social reality; (3) the victimization of the victim through law; (4) the communitarian alternative and the critique of adjudication; (5) the critique of ADR and the discourses of need; and (6) the discursivity of social knowledge.

\section{A. Denial of the Authentic Self}

As previously discussed, post-Realist thought accepts the classical notion that the purpose of substantive civil law is to empower the self. As the handmaiden to substantive law, procedure shares this goal. ${ }^{+0}$ The first theme in the newer literature is the questioning of this notion.

37. See generally Gabel, supra note 31: Tushnel, th Essay on Rights. 62 Trx. L. REv. 1363 (1984). For critiques of the critique of rights, see .Mimority Citiques of the Critical Legal Studies .Momement. 22 HARV. C.R.-C.I. I. RrV. 297 (1987).

38. Sep Gabel, supm note 31: Villmoare, The Left s Poblems with Rights, 9 L.tcal. STUd. F. 39. 42-46 $(1985)$.

39. Sep Gabcl. supro note 31: Tushnet, supra note 37.

40. Sep supra notes $20-27$ and accompanying text. 
This theme emerges with clarity in recent writings on lawyer-client relationships. The sociology of law has long been concerned with this topic. It has recognized that there are potential conflicts between the interests of lawyers and clients. But the literature has tended to focus on ways in which this conflict can be reduced or eliminated by empowering the client so that the lawyer will carry out the client's ends. ${ }^{41}$ The newer literature explores a deeper and more troubling aspect of the lawyer-client relationship: the way in which lawyers create ends so that clients come to want-or at least acceptwhat the system is prepared to deliver. ${ }^{+2}$

Of course, the notion that lawyers manipulate clients so that they will accept the lawyers' ideas as desirable or feasible is not really new. In the Law and Society tradition, this theme goes back at least to Abraham Blumberg's classic study of the way public defenders "cool out" criminal defendants. ${ }^{43}$ This theme also appears in Stewart Macaulay's 1979 study of lawyers and consumer protection, which shows how the lawyers' own political and social visions and their economic interests lead them to redefine complaints brought to them by consumer clients. ${ }^{+4}$ But this idea has been restated recently in more somber tones.

Perhaps the best statement of this theme in the newer literature can be found in Sarat and Felstiner's study of divorce lawyers and their clients. ${ }^{+5}$ Based on observations of lawyer-client interaction and in-depth interviews, this study demonstrates the complex and subtle ways in which a divorce lawyer convinces a client to put aside deep emotional feelings and desires for moral vindication so that the client may accept the resolution that the attorney believes is feasible. ${ }^{4 i}$ The study focuses in detail on the linguistic practices employed by lawyers to reconstruct the client's subjectivity. ${ }^{47}$

Sarat and Felstiner's study illustrates the theme that litigation can constitute a denial of an authentic self, but perhaps this statement oversimplifies the complex argument in this rich ethnographic account. The authors actually describe the process of "legal construction of the client," in which elements of the client's subjectivity are divided into an "emotional self" and a "legal self." +8 They do not explicitly invoke notions of authenticity or denial, yet their article does note that the lawyer "expresses the indifference of the law to those parts of the self that might be most salient at the time of the divorce." "4!

41. E.g. D. Rosenthal, Lawyer and Cilent: Who's in Chakge? 14, 29-61 (2d ed. 1977).

42. Sep Sarat \& Felstiner, Law and Stmegy in the Dinore Lawyer's Office 20 IAw \& Soc'y Rrv. 93 , $116-25(1986)$.

43. Blumberg. supra note 27 , at 28 .

44. Macaulay, supra note 27, at 120-43, $151-66$.

45. Sarat \& Felstincr, supra note 42.

46. Id.

47. Id. at $94-96$.

48 . Id. al $96,116-25$.

49. Id. all 132. 


\section{B. Law and the Construction of Social Reality}

In studies of direct lawyer-client relationships, the newer sociology of law shows a concern with the ways in which contact with the legal process shapes the self, rather than effectuating the ends of a preexistent subjectivity. ${ }^{50}$ The idea that legal discourse constitutes individuals can also be seen in studies that demonstrate that individuals' perceptions of law and their own interests do not predate contact with the legal system but are constructed through such contacts. This idea appears in an even broader form in statements that all social relations, even those not directly affected by contact with the legal system, are shaped or constituted by legal discourse or ideology. ${ }^{51}$

The theme of the legal construction of social reality first arose in the disputes transformation literature. This literature deals with the way in which disputes are defined and changed as they go through their trajectories. Two concepts arose from that literature that influenced later work: Mather and Yngvesson's idea of "rephrasing," 52 and Felstiner, Abel, and Sarat's analysis of "naming, blaming, and claiming." 53 Scholars recognized that the process by which a dispute arises involves three problematic stages: naming a grievance, blaming some actor for the harm, and claiming some relief. ${ }^{54}$ Each of these stages is socially constructed; there are no innate ideas that can be employed to negotiate from a perception of harm to a focused claim. ${ }^{55}$ Prevailing ideas in legal discourse will shape how individuals react to various possibilities, and institutional contacts will channel individual behavior. ${ }^{5 t}$ Further, at each stage of the process the dispute will be rephrased-recast in an institutional discourse that may be very different from the initial understanding of the participants in the dispute. ${ }^{57}$

The recognition of the socially constructed nature of the process of dispute transformation has led scholars to pay attention to the microencounters in which the social meaning of a dispute is negotiated. Studies describe how ideologies about what law is and does are deployed by lawyers and court officials to deter clients and parties from certain choices and to assuage suffering caused by lowered expectations and disappointed hopes. Studies by Merry and by Yngvesson of lower court officials, for example, show how such officials juxtapose official ideologies about law as a formal rightsprotecting system with "street" notions of law as an arena in which

50. Sep supra notes $42-49$ and accompanying text.

51. Trubek \& Esser, supra note 14, at 20-34.

52. Mather \& Yngvesson, Language. Audience, and the Transformation of Dispules, 15 LAw \& Soc'Y REv. 775,777 (1980-81).

53. Felstincr, Abel \& Sarat, The Emergence and Transformation of Disputes: Naming, Blaming, Claiming

15 I Aw \& Soc'y Rry. 631, 634-36 (1980-81)

$54 . \quad 1 d$

55. Id. at 637-39.

56. Itl at $6399-49$.

57. It. at 6.37-39. 651: Mather \& Yingvesson, supro note 52, at 818-21. 
personality and power play a dominant role. ${ }^{58}$ Sarat and Felstiner's studies of the lawyer-client relationship display a similar approach. In their analysis of the ways in which divorce lawyers seek to lower their clients' expectations about what they can accomplish through law, the lawyers deploy a cynical picture of the law as manipulable, cold, and arbitrary. ${ }^{59}$

The recent work on disputes transformation deals directly with litigation and shows how direct contacts with the lawyer and legal system transform or create what individuals seek and expect from civil justice. ${ }^{60}$ But the theme of the legal construction of social reality goes beyond observations of the impact on subjectivity of actual contact with lawyers and courts. It extends to ways in which legal discourse penetrates everyday life, affecting the very definition of relationships and conflicts.

Thus, practices and ideas associated with the law and legal institutions can be seen as structures of meaning that radiate throughout social life and serve as part of the material people use to negotiate their understanding of everyday events and relationships. ${ }^{61}$ The structures of meaning embedded in legal discourse include very basic notions about what kinds of relationships are possible and desirable. For example, legal notions of ownership and property form part of the material used to explain why some people-those who own or manage factories, schools, and other organizations-have legitimate power over others. ${ }^{62}$ Legal notions about how people in intimate relationships should deal with each other affect how people define what they mean by a family. Legal discourse includes subtle methods of valuing certain kinds of behavior, such as instrumental striving for material goods, and disvaluing others.

When scholars say that legal discourses constitute social life, they do not necessarily mean that law is a tight body of closely integrated notions and valuations that filter down from the higher ideological productions of legal thought in some mysterious way into everyone's thoughts and feelings. To be sure, some scholars who write about the way in which legal ideology shapes social perception and channels social behavior speak as if there were a

58. Merry, Concepts of Law and Justire Among Horking-Class Americams: Ideology as Culture, 9 L.EGAI STUD. F. 59 (1985); Yngvesson, Legal ldeology and Commmity Justice in the Clerks Office, 9 L.ecal. STuD. F. $71(1985)$.

59. Sarat \& Felstiner, supra note 42, at 99-116.

[T|he lawyer's description of how judges handle court orders suggests a high level of inattention and routinization. Judges sign orders without reading them to satisfy "people who really need this stuff." While the judge is said to ignore the substance of the order, he does pay attention to the lawyer or law firm who requests it. The legal process is thereby portrayed as responding more 10 reputation than substantive merit. Thus, the client is introduced to a system that is hurried, routinized, personalistic, and accident prone.

Id. at 100

60. See, e.g., id. at 107-08.

61. Gordon, Neu' Dexelopments in Legal Theory, in Tuf. Pol.tucs of Iaw: A Progressive Critique 287-89 (D. Kairys ed. 1982)

62. Fischl. Some Realism Aboul Crilical Legal Suldes. 41 U. Miami I. Rrs. 505, 526-28 (1986). 
relatively cohesive and widely diffused legal ideology, ${ }^{63}$ but others see the process as extremely loose and malleable. ${ }^{64}$

The position a scholar takes on the malleability question may depend on the socio-theoretical origins of the notion of social construction that an individual scholar employs. The theme of the legal construction of everyday life draws on several bodies of social theory, including critical anthropology, neo-Marxist structuralism, Critical Legal Studies, and post-structuralist literary theory. All of these social theories see law as one of several discourses of power or ideological structures that reinforce relations of power and conditions of hierarchy. They differ, however, in their views of how discourse structures relationships. For some at the post-structuralist end of the spectrum, the process is highly diffuse and ad hoc; actors deploy bits and pieces of various discourses as they negotiate everyday relationships. ${ }^{65}$ At the other end of the spectrum, neo-Marxist structural accounts see ideology as firmly rooted in well-organized structures of power and transmitted through a series of mutually reinforcing and hegemonic practices. ${ }^{66}$

The idea that everyday understanding incorporates views produced and reproduced by the discourses of the law is drawn from disparate strands of contemporary social theory that picture legal ideology differently. Nevertheless all these theories see law as one of several discourses or ideologies that reinforce relations of power and conditions of hierarchy. Where the liberal view sees law as a shield for autonomy and an instrument for realizing authentic projects, these critical social theories see legal ideas and institutions as part of complex processes through which the self is actually constituted by social relationships and discourses. To one degree or another, all assert that this social construction of the self through ideology and language suppresses the full potential of the self. ${ }^{67}$

\section{Law and the Victimization of the Victim}

The third theme in the newer literature is "the victimization of the victim" by law. This term comes from a recent study of antidiscrimination law by Kristin Bumiller entitled The Civil Rights Society. ${ }^{\text {ix }}$ This book, which examines how victims of discrimination experienced the law and their contacts with litigation, incorporates several of the themes emerging in the critical sociology of procedure. Bumiller explores conflicts between the use of law and realization of the self, ${ }^{69}$ shows how law is used in everyday discourse to

63. See Hunt, The Ideology of Laul: Adtances and Problems in Recent tpplications of the Concept of Ideology? to the Analysis of Law. 19 LAw \& Soc'y Rev. 11 (1985). See also Trubek. IThere the Aclion Is: Critical Legal Studies and Empiricism. 36 Srav. I. Rev. 575. $610-15$ (1984); Trubek \& Esser, supra note 14, at 27.

64. Sep Coombe, Room for . Manoenuer: Toulard a Theory of Practice in Critical Legal Studies, I4 I. IW \& SOC. Inquiry 69 (1989).

65. Sep id. at $91-93$

66. Sep Hunt, supra note 63, at 13-19.

67. Sep. p.g. Cabel, supme note 31 .

68. K. Bumill.t. The Civil. Ricirts Society 2 (1988).

69. It al 109 . 
construct identity, ${ }^{70}$ and recognizes that the way social knowledge is constructed affects the nature of the society we live in. ${ }^{71}$

Bumiller's central argument, however, is that "antidiscrimination law serves to reinforce the victimization of its "beneficiaries." "72 She recognizes that law may fail to respond to the demands of the subject, as Sarat and Felstiner suggest; she also recognizes that legal discourse plays a role in the construction of our identities, as the writers on legal ideology argue. But Bumiller goes even further: In her critique of antidiscrimination law she contends that, in actual operation, this body of law and the procedures associated with it may have an effect directly opposed to the law's alleged purposes. If antidiscrimination law victimizes its putative beneficiaries, it does not just fail to prevent discrimination; it perpetuates it. ${ }^{73}$

Bumiller reaches this radical conclusion through a rich and complex argument that goes well beyond questions of procedure, even as it is most broadly defined. The study, however, contributes directly to our understanding of the social visions underlying procedural thought. Bumiller's study challenges some of the reigning assumptions about litigation and procedure. She has a devastating critique of the implicit psychology employed in much thinking about procedure, and she places in question Realist and post-Realist assumptions that more effective procedural mechanisms can, by enhancing access to justice, easily guarantee that rights will be made effective.

Bumiller's study started with the observation that people who perceived themselves to be discriminated against are much less likely than others who perceive harms either to complain or to seek legal redress. ${ }^{74}$ In her research, she sought an explanation for these disparities. Her method was to explore

70. Id. at $30-33$.

71. Id. at 32-38. Bumiller explicitly seeks a social science method which will reveal the victim's perspective and, by so doing, create the possibility for social transformation. Concluding the methodological section of the book, she says: "This work is motivated by the desire to make social science research more responsive to the problem of social oppression and the stultifying reality of everyday life ... I hope that the interpretation of these social realities can create a liberating vision of alternative possibilities." Id. at 38. For a fuller description of this theme. called herein the discursivity of social knowledge, see imfra notes $107-13$ and accompanying text.

72. K. Bumillek, supra note 68 , at 39 .

73. It is useful to note the difference between Bumiller's critique of antidiscrimination law and more conventional analyses of the failure of legal reform by Law and Society scholars. As Sarat has pointed out, one of the staple products of $\mathrm{L}$ aw and Society research is the gap study, which measures the gap between the goals of legal policy and the results that legal policy produces. Sarat, I.egal Effectiveness and Social Sudies of Laul: On the (infortumate Persistence of a Research Tradition. 9 L.eGat. STUD). F. 23 (1985). Such studies recognize that legal reforms may fail to achieve their goals, such as elimination of racial discrimination, but they do not question the legal order's commitment to these goals. Bumiller's analysis of antidiscrimination law, on the other hand, challenges this commitment. She explicitly rejects the gap study approach to the study of civil rights laws. K. Bumit.ter, supra note 68, at 25-26. Rather, she stresses the positive ways in which the existence of antidiscrimination law reinforces victimization. Id. at 2, 39. Thus, she suggests, protective legislation may result in perpetuation of patterns of behavior that maintain discriminatory practices. Sep id. at $110-11$.

74. K. Bumiller, supm note 68 , at 26-30. These observations were drawn from a nationwide survey conducted by the Civil Iitigation Research Project. For a complete report of the survey, see Miller \& Sarat, Criezences, Claims, and Dispules: Assessing the Aduprsary Culture, 15 I aw \& Soc' Y Rri. 525 (1980-81). 
the psychology of discrimination victims through in-depth interviews. ${ }^{75}$ These interviews led Bumiller to develop an account of the psychology of people affected by discrimination which is directly at odds with the implicit psychology in mainstream thinking about civil procedure.

As previously suggested, the mainstream tradition assumes that autonomous subjects are motivated to secure knowledge of their rights and to pursue them through litigation if necessary. In this social vision, litigation is a natural act through which the individual affirms her will. This individualist, will-based account was central in classical thought and was not significantly changed by the Realists. Realism recognized that rights may be uncertain, and that there may be economic and institutional barriers to litigation, but the Realists did not question that people would be motivated to assert rights that had been set forth in the law and thus publicly known.

In her analysis of victims' motivations to use and not to use antidiscrimination law, Bumiller argues that there are strong psychological barriers that prevent discrimination victims both from perceiving discriminatory acts as violations of legally cognizable rights, and from asserting such rights if they do. She notes that in order to become a plaintiff in an antidiscrimination complaint, a person must state that he has been victimized. ${ }^{76}$ "That is, the very act of using the law demands the assumption of the label of "victim" of proscribed actions. But, she stresses, much in the lives of the people she studied causes them to want to avoid taking on the "mask of the victim." ${ }_{7}$ The class of people allegedly protected by antidiscrimination law is subjected to constant assaults on its identity by racism, sexism, and other sources of hostility. ${ }^{7 \times}$ To deal with these threats, Bumiller posits, people in a supposedly protected class develop what she refers to as an "ethic of survival," which stresses their capacity to cope with unjust situations. "79 To claim victimhood publicly, as the law demands, threatens the sense of control which people in this situation derive from this ethic. ${ }^{80}$

Bumiller does not assert that this coping strategy is the sole reason why victims may not be able to see their situations as violations of legal claims. The other side of the picture is their fear of the law and the power of the organizations against which they would have to assert claims. The law seems alien and uncertain, and their opponents powerful and knowing. To use the law, they must portray themselves as victims, thus giving up a self-identity that has allowed them to cope. But this sacrifice will not guarantee success; quite the contrary, they often think that they will lose in court even if they deeply believe that an injustice has occurred. These peoples' fear of losing control far exceeds their hopes for vindication through law. Thus, Bumiller concludes:

75. K. Bumiller, supra note 68, at 29-30

76. Id. at 99 .

77. Id. at 62-64.

78. Id. al 84 .

79. Id. at $78-97$

80. Ill at $93-95$. 
The results of my interviews show that people who have experienced discriminatory treatment resist engagement in legal tactics because they stand in awe of the power of the law to disrupt their daily lives. At the same time, they are cynical about the power of the law actually to help them secure the jobs, housing, and other opportunities they lay claim to. They fear that, if they seek a legal resolution, they will not improve their position but will lose control of a hostile situation. These respondents also feel that asserting their legal rights would not enable them to express their sense of dignity but would force them to justify their worthiness against a more powerful opponent. ${ }^{81}$

Bumiller demonstrates that law threatens dignity and involves the risk of losing a sense of autonomy and control, but she reports an added note of cynicism-the belief that a person will not only lose his authentic self if he enters the legal system, but he will not get anything in return since the law is powerless. Thus, Bumiller is critical of the way in which the whole structure of civil rights law works. She argues that a system that forces the victim of discrimination to become a victim of the legal process in order to remedy the original harms is a system that cannot work. Indeed, the victims she describes are in a classic Catch-22 situation: They can restore the dignity they have lost through discrimination only by submitting to the indignity of the law. Because it is clear that only a few hardy (or foolhardy) people will do so, she suggests, the law will always fail to reach its ostensible goals. ${ }^{82}$ Finally, the practical hollowness of the promise casts doubt on the sincerity of the promise itself. If the legal system were really interested in stopping race, age, and gender discrimination, would it have forced the victims into the Kafkaesque situations that Bumiller's respondents' stories describe? Those who accept the argument of this study will not imagine that some new procedural devices will serve to cure the fundamental flaws to which she has pointed.

\section{The Communitarian Alternative and the Critique of Adjudication}

The critical literature discussed so far deals primarily with the discursive constitution of subjects. Studies of lawyer-client interaction, the ideology of the law in everyday life, and the victimization of the victim challenge the liberal account of the autonomous subject. But Law and Society scholars have also contributed to the development of a more communitarian perspective on litigation. In so doing, they have contributed to an understanding of implications that the idea of a contextual self might have for civil procedure.

To be sure, these efforts neither amounted to a full-blown communitarian theory of justice nor led to widespread legal reforms. Nevertheless, Law and Society scholars did articulate some criticisms of adjudication that reflected dissatisfaction with liberal ideas about the relationship between law and society, and their work did lend some support to radical efforts to develop new methods to handle disputes.

There are two themes in the Law and Society literature that suggest the presence of communitarian concerns: (1) concern about the impact of dispute

81. Id. at 109.

82. See supra notes $72-73$ and accompanying text. 
processing on social relationships; and (2) interest in communal sources of normative order.

One major concern of Law and Society work on litigation has been the fear that adjudication is harmful to long-term social relationships. ${ }^{8: 3}$ Law and Society scholarship highlighted several features of adjudication that could make it difficult for parties to continue social relationships if they had to go to court over disputes within the relationship. Among these were: the winnertake-all aspect of civil remedies, in which normally one party must win everything and the other lose all; the structure of the adversarial system, which encourages each side to push its case to the full; and the backwardlooking feature of adjudication, which seeks to resolve issues in the past, rather than look for ways to maintain relations in the future. ${ }^{8-4}$ Because of these aspects of adjudication, persons in long-term relationships who have disputes might have to choose whether to enter the courts and sacrifice valued relations, or to shun the courts and thus be denied a forum to air grievances. ${ }^{85}$

The second communitarian theme concerned the use of norms drawn from living communities to resolve disputes. Critics of formal legal institutions thought that justice would be better served if the norms employed in dispute processing were drawn from the communities in which people lived their lives. In that way, communities would be strengthened and disputes handled more effectively. ${ }^{x i}$

One institutional project reflected both these concerns: the effort to develop community-based mediation for many disputes. ${ }^{87}$ This short-lived movement sought to create another kind of justice. By using mediation instead of adjudication, it sought to encourage the preservation of troubled relationships. By drawing mediators from the community, it sought to strengthen communal institutions in an increasingly atomistic society.

The critique of formal justice and interest in community-based mediation reflect a vision of self and society very different from the liberal individualism that still dominates mainstream thinking about civil procedure. To be sure, this alternative vision was never fully developed. Scholarly concern over the impact of adjudication on social relationships did not lead to any major

83. Among the factors that generated these concerns were the findings of legal anthropologists concerning models of dispute processing in non-Western societies. These models, it was believed, differed from the approach of civil procedure in Western courts. For example, reporting on the operation of a Mexican Zapotec court, Laura Nader noted that among the features of Zapotec dispute processing were compromise solutions and consideration of the relevance of networks of social relations, features not normally associated with Western models of adjudication. Nader, Styles of Court Procedure: To llake The Balance, in Law in Culturf, \& Socifry $87-88$ (L. Nader ed. 1969).

84. See Silbey \& Sarat, Dispule Processing in Lau and Legal Scholarship: From Institutional Critique to the Reconstruction of the Juridical Subject, 66 Denver U. L. REv. 437, 452-54 (1989). Sep gemerally Yngvesson, Re-examining Continuing Relations and the Late, 1985 WIS. L. REv. 623.

85. Silbey \& Sarat, supra note 84 , at 454.

86. This was an implicit ideal in the literature of legal anthropology. See. e.g. Nader. supra note 83. See also Galanter, Justice in .1/any Rooms: Cousts. Priwate Ordering. and Indigenous I.au. 19 J. LECM. Pluralism \& Unoficiat. I. I (1981).

87. For a full account, sec Wahrhafig, An Overrieut of Community-Oriented Citisen Dispute Resolution Programs in the ('mited Siates, in 1 Tur: Polirics of Informal Justict 75 (R. Abel ed. 1982). 
rethinking of the ideals of legal individualism. Law and Society scholars, by and large, were content to observe that relational concerns might explain some patterns of court use and non-use, while the proponents of communitybased mediation were concerned with small-scale local reforms, not sweeping social transformation. Moreover, even the modest reform proposals that came out of this era largely failed, and the community-based mediation movement was swallowed up by moves to institutionalize ADR within the court system itself. ${ }^{88}$

Nonetheless, these modest efforts did point away from the individualist model of justice still prevalent in mainstream thinking, suggesting the emergence of doubts about classical notions of autonomous selfhood. Indeed, in a recent discussion of the movement to create alternatives to adjudication, Robert $\mathrm{A}$. Baruch Bush argues that, within this movement, one can discover a "Communitarian or Relational vision of society in which the greatest good is the connection of the individual self to others in interpersonal and communal relations." "') Bush notes, however, that this vision is only one of several to be found in the ADR movement, and that to date it has not been adequately developed. ${ }^{90}$

\section{E. The Critique of ADR and the Discourses of Need}

Law and Society scholarship, however, has not sought to develop the communitarian vision latent in the critique of formal justice. For complex reasons, the emphasis in recent scholarship has shifted to a critique of the ADR movement itself. This is a rich literature, in which many issues are pursued." Only one is mentioned here: the critique of the use of a behavioral science discourse of need as a justification for ADR. In recent years it has been suggested that the behavioral sciences offer a resource that can be used to resolve some kinds of disputes, especially marital disputes, better than they can be handled through adjudication." The argument for the use of such ADR techniques as divorce mediation has met with strong criticism from the Law and Society community. This literature raises once again the question of the discursive constitution of subjectivity.

The discourses of need, which have come under critical attack, are based on a redefinition of the self and part company with classical liberal notions. But the self that emerges from this linkage of ADR and the behavioral sciences is both dependent and decontextualized. For this reason, critical sociologists of law have challenged behavioral science justifications of ADR. 93

88. Silbey \& Sarat, supra note 84, at 455-57.

89. Bush, Defining Quality in Dispute Resolution: Taxonomies and Anti-Taxomomies of Quality Arguments, 66 DEN. U.L. REv. 335, 376 (1989). Bush sees the whole ADR movement as a potential move towards a relational vision, but fears that the communitarian vision may be overwhelmed by other approaches. Id. at $378-79$

90. Id. at 379 .

91. See, e.g., Tine Politics of Informal. Justice, supra note 87 (two vols.).

92. Sep generally Milne \& Folberg. The Theory and Pratice of Dizorce Vediation: th Overifie, in Divorce. Mediation: Theory and Practice (J. Folberg \& A. Milne eds. 1988).

93. Silbey \& Sarat, supra note 84, at 470-96. 
In the eyes of the critics, some ADR proponents want to redefine the legal subject as a source of needs, not a bearer of rights. As Silbey and Sarat have noted, "[i]n the move [from rights] to needs the juridical subject is provided with a more complicated, richer human character. Yet that character stands at some distance from itself and, as a result, presents an incomplete understanding of 'real' needs." 94 The newly defined subject paradoxically is radically dependent upon, yet extracted from, social context. In brief, this subject has no language with which to deal with uncompromisable issues.

These critics seem to be searching for a contextual vision of the self. Yet, unlike some earlier Law and Society scholars, they see ADR in negative terms. The revision of the self implicit in the move to the discourse of needs, they fear, may be worse than the liberal view it replaces. This critique of ADR has two dimensions. The first challenges the way in which informal processes change the questions that the law asks. Thus, it is suggested that ADR has shifted the epistemological foundations of the law. As a result, "[r]ights talk is by no means displaced; it is, however, transformed, and, in some ways domesticated, in the face of the discourses of interest and needs." 95 The shift from vindication of rights to satisfaction of needs changes the way in which conflicts will be resolved. New modes of expressing and realizing needs are valorized, and everything becomes a problem of personality; how to change, modify, and mold behavior become the key questions. ${ }^{9 ;}$ At the same time, needs become reified and come to reflect some essential component of human nature; they therefore embody some universal essence which all can recognize and share. ${ }^{97}$ The problem with this epistemological shift is that a different and, in many cases, hidden authority is created for and by specific actors in the legal system whose job is to service needs. A new and arguably more insidious form of control is instantiated in this microphysics of power. ${ }^{98}$

The second element of the critique focuses more on changes in outcomes associated with the shift to ADR. Where the first element highlights the subtle power shifts within law associated with the discourse of need, the second focuses on who wins and who loses in the new systems. The second element of the critique has focused on divorce mediation, one of the most significant results of the ADR movement.

Perhaps the most powerful voice in the critique of the effects of ADR and the discourses of need is family law scholar Martha Fineman.9. Fineman shares with the critical sociologists a concern for how behavioral discourse has come to replace rights analysis, but she relates this to a very concrete set of concerns-the impact of these changes on divorced mothers. ${ }^{100}$ Fineman's

94. Id. at 491 .

95. Id. at 497 (foomote omitled).

96 . Id. at $490-96$.

97. Id. at $492-94$.

98. Sep M. Foucantit, Discipinn and Punisu, supra note 28, al 139.

99. Fincman, Dominant Discourse, Professional Language, and Legal Change in Child Custody Derisionmaking. 10I HARV. I. REV, 727 (1988).

100. It at $729-30$. 
argument is impassioned and contextualized. By focusing on effects as well as processes, she shows precisely and eloquently why the shift to the needs of the emotional self has been deleterious.

Fineman's argument, in short, is that the behavioral science rhetoric of social workers has come to dominate legal decisionmaking, thereby constructing a hegemonic enclave in which social workers can advance their own professional interests. Her argument suggests that, like Silbey and Sarat, ${ }^{101}$ she fears that the reconstruction of the law by the discourses of need will permit an even more finely controlled mapping of behavior. ${ }^{102}$ What makes Fineman's argument particularly compelling is that she shows how this situation is actually a tragedy for many divorced mothers.

Once assigned a relatively minor role in the divorce process under the fault system, social workers in the no-fault divorce era have redefined divorce as an emotional crisis. ${ }^{103}$ Billing themselves as experts in the management of emotions and therapeutic reconciliation, they have effectuated dramatic changes in the divorce process; in particular, they have been key actors in redefining the standard for child custody from the "best interest of the child" to joint custody.104 Divorce, once a potentially emancipatory event for women, becomes a condition of continued dependency because of the demand that ongoing relationships be retained between divorcing spouses. The power of the dominant discourses of the helping professions maintains the indeterminate legal status of mothers and children by focusing on the need to keep the family together at least symbolically, if not concretely.

Fineman's account of divorce mediation makes it look like the utopian moment in ADR gone awry. Rather than deal with the concrete experience of a self defined by context, the social work profession and the mediation process have helped to create a series of fictions that many want to believe: Men and women have equal interests and abilities to parent; relationships never have to end acrimoniously, but can always be worked out; and men and women are equal in economic and symbolic terms. ${ }^{105}$ Yet the result of these fictions is that this discourse "has created rather than reflected reality." 10 is What Fineman's article indicates is that the experience of many individuals does not comport with these fictions. In effect, the legacy of ADR is the circulation of a certain type of discourse that aggrandizes sharing, caring, and ongoing relationships embedded in a continued familial structure, while effectively ignoring the contextualized self. In the name of contextualization, this discourse creates an illusory subjectivity which can then be controlled by the discourse of need.

101. Sibey \& Sarat, supra note 84 , at $490-96$

102. Fincman, supra nole 99, at 733, 744-60.

103. Id.

104. Id. at $731-35,740-44$.

105. Id. at 731-35, 744-45, 751 n.102.

106. Id. at $76 \mathrm{l}$. 


\section{F. The Discursivity of Social Knowledge}

The final theme that one can detect in the work of many scholars who are producing the newer literature on civil disputes, litigation, and procedure deals not with law but with social knowledge itself. It represents a rethinking of the nature and purpose of empirical research. This rethinking is not limited to the disputes and litigation area but affects the whole of social science research in and about law. Many of the scholars who have written extensively about litigation, lawyer-client relationships, ADR, and the other themes outlined above ${ }^{107}$ have at the same time been engaged in a broader epistemological critique. As a result, their work in the sociology of civil procedure manifests a different attitude toward the process of research than that reflected in most of the post-Realist Law and Society work.

The term "discursivity of social knowledge" refers to the idea that fields of knowledge such as legal scholarship and the sociology of law are discourses that contribute to the construction of society, and not neutral mirrors that simply reflect an objective social reality. In recent years, scholars in many fields have come to realize that representations of society affect the way in which society is understood and organized. ${ }^{108}$ This recognition has led them to accept the proposition that scholars have a responsibility to investigate the values their work embraces and the social projects it supports. In the Law and Society tradition, this recognition has caused some to question whether the sociology of law has been sufficiently attentive to the effects produced in society by its choice of questions, its methods of inquiry, and its techniques of interpretation. ${ }^{109}$ Furthermore, recognition of discursivity has led Law and Society scholars to seek more distance from official dogmas, policy goals, and alleged reform agendas. ${ }^{\prime \prime \prime}$

The impact of this new consciousness can be seen in the literature reviewed above and in the themes it has generated. Two salient features of this work stand out. First, there is a willingness to question the broader social vision embodied in current thinking about law and enshrined in current procedural institutions. As has been shown, the newer literature does not take for granted the stories that mainstream legal thought tells about the nature of self, society, and law. Rather, the authors of the newer literature

107. Noleworthy among these are Kristin Bumiller. Austin Sarat, and Susan Silbey. For a discussion of Bumiller's views on social knowledge, see supm note 71 . Sarat and Silbey have written extensively on these questions. See supra note 24 and sources cited therein.

108. Examples of this can be found in feminist scholarship. See generally Frmivis? Studies/Critical Studies (T. de Laurctis ed. 1986): C. Wefdon, Feminist Practice ani) Poststructuraist Timory (1987). For examples in other fields, see A. Giddens, lins. Constitution of Society: Outline of The Theory of Structuration (1984) (sociology): Collicer \& Yanagisako. Towerd a ('mified Analysis of Gender and Kinship, in Gender and Kinship: Essays Toward a Unifito ANALYsis 14 (J. Collier \& S. Yanagisako eds. 1987) (anthropology).

109. For a review of some recent Law and Society work that has begun to recognize that social knowledge constitutes society-that is, is discursive-and the implications of this recognition on questions, methods, and interpretive techniques, see Trubek \& Esser, supra note 14. Sep also Trubek. supra note 63.

110. Sep. P.g.. Silbey \& Sarat, The Pull of the Poliry Audience, supra notce 24 
recognize that these stories rest on contestable social visions. They are prepared to bring these contestable assumptions to light for critical evaluation. And they have shown a willingness, at times, to assert alternative visions like the communitarian notion of the contextual self.

Second, these authors are willing to articulate the voices of people and groups who are affected by the law but whose perspective is overlooked or downplayed in mainstream thought. These authors are self-conscious about their role in a process of the construction of fields of knowledge that will have an impact on social life, and they are concerned that this process reflect viewpoints other than those of academic elites. This concern is apparent in the way Sarat and Felstiner show us the perspective of clients whose hopes for the law are dashed by the manipulative behavior of lawyers." 1 It is clear in Bumiller's self-conscious decision to provide a voice for women of color and other victims ensnared in a legal process ostensibly designed to protect them. ${ }^{112}$ This concern comes through most forcefully in Fineman's impassioned efforts to demonstrate how the interests of divorced mothers and their children have been overlooked by those who seek to transform the processing of divorce law through the introduction of the discourses of need. ${ }^{113}$

\section{VI}

\section{Conclusion}

The combination of themes emerging in the sociology of civil procedure demonstrates how the development of a critical practice is taking Law and Society scholarship beyond the limits established in the post-Realist period. The scholars whose work has been summarized here are a small group, and their work makes up a modest portion of all the empirical research being done today on disputes, litigation, and procedure. But because they have staked out a new and more critical role for empirical scholarship, their initial efforts represent an important and novel phase of the empirical tradition initially launched by the Realists as an instrumental adjunct to procedural reform. Started as a largely technical handmaiden to the work of mainstream reformers, the sociology of civil procedure is moving toward a full-blown critical practice in which Law and Society scholars are as likely to question the goals of the legal system as to embrace them. That move, if fully carried out, would be the true handmaiden's revenge.

111. See Sarat \& Felstiner, supra note 42.

112. See K. Bumiler. supra notc 68: Bumiller, lirtims in the Shadou of the Law: I Critique of the . Iodel of Legal Protection. I2 Sicns: J. Women Culturt \& Soc'Y 421 (1987).

113. Fincman, supm note 99. 